\title{
Emission Study and Pollution Haven Hypothesis in Economic Development of Developed Country
}

\section{Evi Susanti Tasri and Kasman Karimi}

Department of Economics, Economics Faculty, Bung Hatta University

\section{Abstract}

This study aims to study at the emission level of $\mathrm{CO} 2$ in the group numbers of developed countries and attempt to look at the pollution haven hypothesis, whether it is happen in the group of developed countries. By using panel data analysis in this study, it finds that the significant variable influenced $\mathrm{CO}_{2}$ in developed countries are GDP, FDI and Population. In this research, $\mathrm{FDI}$ has a negative effect in emission level of $\mathrm{CO}_{2}$ and GDP and Population have the positive one. From this study, it founds that in the developed countries that has been studied has proven that there is no pollution haven hypothesis.

Corresponding Author: Evi Susanti Tasri evitasri@yahoo.com

Received: 18 January 2019 Accepted: 24 March 2019 Published: 31 March 2019

Publishing services provided by Knowledge E

(c) Evi Susanti Tasri and Kasman Karimi. This article is distributed under the terms of the Commons Attribution License, which permits unrestricted use and redistribution provided that the original author and source are credited.

Selection and Peer-review under the responsibility of the First ELEHIC Conference Committee.

\section{G OPEN ACCESS}

This is supported by the finding of a negative relationship between $\mathrm{FDI}$ and $\mathrm{CO}_{2}$ emissions, and this relationship is at a significant level. Econometrically, this research model is considered good with the R-squared value level is 0,998.

Keywords: $\mathrm{CO}_{2}$ emission, $\mathrm{FDI}, \mathrm{GDP}$, Population

\section{Introduction}

The economic development carried out should not only pay attention to the level of economic growth achieved, but the negative effects generated during the development process carried out should also be a serious concern. Economic development carried out has a negative effect on the environment in the form of pollution. The negative effects posed in the economic development process lead to many studies of pollution analysis by macroeconomic indicators. One study that is well known in the economy is the Pollution haven hypothesis. Pollution havens are found in countries with low environmental standards. Pollution haven hypotesis refers to the possibility that trade liberalization causes industrial pollution movements from high income countries to countries that have low environmental standards [1]. Pollution levels in a country are closely related to economic growth but on the other hand trade liberalization and foreign direct investment (FDI) are important engines for economic growth that increase along with the flow of economic globalization. Then the direction of trade between countries 
can be influenced by environmental regulations that will determine how much the negative impact of development on the environment can be controlled. Pollution haven hypothesis argues that when countries that have large industries try to establish factories or offices abroad in the hope of getting the resources and labor they need in developing countries easily and cheaply. In developing countries, industries from developed countries get resources and labor easier and cheaper because developing countries have less stringent environmental regulations. On the contrary, the state which is strict on environmental regulations makes investment costs more expensive for companies. Thus, companies that invest physically overseas tend to look for countries that have low or not strict environmental regulations. An economic approach is one approach that can be used to overcome the problem of scarcity of natural resources and environmental damage [2]. The relationship between economic growth and environmental pollution, implied in the pattern of relations, became known as the Environmental Kuznezts Curve (EKC). The concept of the Kuznets curve is used to explain the pattern of relationships between measurements of environmental quality and per capita income [3].

Global warming climate change and the depletion of the Ozone layer make the ice north and south cube melt so that the volume of sea water increases. This condition if it is increasingly allowed will have an impact on the reduction of land which is a place for the survival of living things, especially for humans. The following condition that is feared to occur is a scarcity of resources due to the increasingly reduced life support.

This situation occurs due to over-exploitation and does not pay attention to its impact on environmental destruction in the future. Development of the industrial sector is a top priority in developing countries (NSB) development plans. This happens because the industrial sector is considered as the leading sector that is able to encourage the development of other sectors, such as the service sector and agriculture [4].

National development activities have a tendency to be oriented towards increasing economic growth, while the source of economic growth to date is still based on the use of natural resources. Industrial activities and the continuous use of natural resources will cause negative externalities for the environment in the form of pollution and environmental damage. Externalities occur when someone does an activity that has an impact on others, both in the form of benefits and external costs that do not require an obligation to receive or pay for it [5].

Air pollution is one of the environmental damage, in the form of decreasing air quality due to the entry of harmful elements into the air or the atmosphere of the earth. The dangerous elements that enter the atmosphere can be carbon monoxide (CO), Carbon dioxide $\left(\mathrm{CO}_{2}\right.$, sulfur dioxide $\left(\mathrm{SO}_{2}\right)$, and other pollutants. $\mathrm{CO}_{2}$ is in the form of gases in 
standard temperature and pressure conditions and is in the Earth's atmosphere. Carbon dioxide is the result of burning organic compounds, carbon dioxide is also produced by various microorganisms in fermentation and exhaled by animals, plants absorb carbon dioxide during photosynthesis, therefore as a greenhouse gas and in low concentrations, $\mathrm{CO}_{2}$ is an important component in the carbon cycle. animals and plants, $\mathrm{CO}_{2}$ is also a by-product of burning fossil fuels, carbon dioxide is a large part of the gas responsible for the greenhouse effect in the atmosphere.

The increasing threat of global warming and climate change has become a concern of many circles, it has focused special attention in the economic field regarding the relationship between economic growth and environmental degradation. The Intergovernmental Panel on Climate Change reports that the average temperature of the earth is expected to rise between 1.1 and $6.4 \mathrm{oC}$ in the next 100 years [6].

According to the EKC hypothesis, at the take-off stage of development and progress in industrialization it can increase environmental damage due to greater use of natural resources, excessive pollutant emissions, less efficient and relatively dirty technology operations, and ignore the environment as a consequence of growth. In the process of development and the progress of industrialization which is characterized by the use of resources renewable and non-renewable, positive and negative impacts will emerge.

The positive impact of the utilization of these resources is an increase in living standards and welfare of the people, while the negative impact is the emergence of pollution that must be handled from uncontrolled use of resources due to the production and consumption process. Thus, increasing high economic growth turns out to be very expensive to pay with the increasing pollution and environmental damage. The deterioration of environmental conditions can be an obstacle in creating a sustainable economic development that requires the concern of all parties.

According to data released by the World Resource Institute (WRI) based in Washington $\mathrm{DC}$, emissions of carbon dioxide $\left(\mathrm{CO}_{2}\right)$ produced by countries in the world are as much as 47.59 billion tons of $\mathrm{CO}_{2}$ emissions $\left(\mathrm{MtCO}_{2} \mathrm{e}\right)$ per year. Of these, the country with the largest contribution in producing carbon emissions in the world is China (China) with 10.68 billion tons of $\mathrm{CO}_{2}$ emissions per year. The it is followed by the United States which ranks second as the largest emitter of carbon dioxide in the world at 5.82 billion tons of $\mathrm{CO}_{2}$ emissions per year. The third place is occupied by 28 countries that join the European Union with the amount of carbon dioxide emissions produced at 4.12 billion tons of $\mathrm{CO}_{2}$ emissions per year. Indonesia is also on the list, which ranks 6 th with carbon dioxide emissions produced at 1.98 billion tons of $\mathrm{CO}_{2}$ emissions per year. [7]

Based on the background above, then the research questions in this study are: 
1. What is the influence of Gross Domestic Product, Foreign Direct Investment, Domestic Investment, Population, and Industrial Sector Contributions to Air Pollution?

2. Is Haven Hypothesis (PHH) Pollution proven in developing countries?

\section{Literature Reviews and Hyphothesis}

A number of studies examined the relationship between economic growth and environmental quality, but at present, studies of economic growth relationships that try to see macroeconomic indicators with air pollution and the enactment of pollution haven are still not widely performed. Economic variables that are thought to affect the level of $\mathrm{CO}_{2}$ emissions include:

\subsection{Bruto of domestic product and air pollution}

The impact of economic growth on environmental quality as measured by greenhouse gas emissions, namely through emissions of Carbon dioxide $\left(\mathrm{CO}_{2}\right)$, Methane $(\mathrm{CH} 4)$, and Nitrogen Oxide $\left(\mathrm{N}_{2} \mathrm{O}\right)$ with the Environmental Kuznets Curve model. Economic growth at a low income level (before the turning point) will increase environmental degradation, but at more income levels (after a turning point) high economic growth will provide improved environmental quality [8].

In the early stages of development in a country that is still developing industries to increase air pollution output also increases. But countries that have increased economic growth will have the ability to control this pollution. After the state has succeeded in developing methods and procedures to control pollution, the level of pollution can be detained and can even be reduced in line with economic growth. Country capability will also be used to improve air quality. In the end the country will develop technologies that are environmentally friendly so that pollution can be reduced. When a country experiences increasing growth, the problem of air pollution increases rapidly. This occurs before stabilization or control of air pollution has not been implemented. [9]

\subsection{Effects of foreign direct investment on air pollution}

Foreign investment is a form of economic openness other than international trade. The concept of openness benefits the economy through international trade, international capital transactions and the exchange of international knowledge and information. 
Openness in terms of foreign capital can accelerate economic growth because with foreign investment coming in, it can add factors to domestic production both in terms of quantity and quality which then drives economic growth. In a previous author's study [10], it was found that trade openness significantly affected green GDP, this is because the more open the economy of a country the higher the level of exploitation of natural resources, which ultimately reduces the availability of resources for the next development process, so that economic development continuous worry can be realized.

In an open economy, the world financial market is another source of domestic investment and a source of outflows for domestic savings. In this connection, foreign direct investment plays an important role in driving economic growth rates for several reasons [11]: (1) countries can access technology from more developed countries and therefore play a leading role in improving technology for countries recipient (2) direct foreign investment can promote growth through the creation of spillover effects. (3) Foreign companies tend to be more productive than local companies, and (4) if there is a complementary relationship between foreign direct investment and trade, FDI can increase the volume of international trade.

The growth of foreign direct investment carried out by the private sector, namely, the investment funds are directly used to carry out business activities or to hold equipment or production facilities such as buying land, opening factories, bringing in machinery, buying raw materials, etc. in third world countries has been going very fast in the last few decades. But unfortunately the attention of investors is only focused on maximizing profits or the level of yield for every penny of capital they invest. That is why more than 90 percent of private foreign investment funds have flowed to developed industrial countries and some developing countries whose economies are the most dynamic and have relatively rapid growth [12].

Developing countries also have an interest in the occurrence of environmental degradation. While there are several studies that examine the relationship between environment and economic growth in several developing countries [13] in Cote Ivory, Morocco, Mexico and Venezuela. While many researchers found the effects of significant and negative pollution from FDI, some others did not find or statistically significant pollution effects.

In a study that examined the relationship of FDI and air pollution in China, it was found that FDI did not have a negative impact on air quality in China. The reason is that low FDI inflows to cities [14]. The economy of the country that gets most of its income from natural resources cannot preserve growth by replacing accumulated physical capital for increasingly bad natural capital. The environmental degradation that occurs tends to 
torment the poor, because they often depend on natural resources to earn their income, and there is very little possibility of being able to replace the assets used. Especially in the long run the approach that pays attention to the quality of the environment and the efficient use of natural resources will contribute to economic growth, as well as human welfare.

While a number of other writings provide evidence that FDI has a positive impact on air quality. [14] argue that the environmental impact of FDI depends on the source of investment. While FDI from Taiwan, Hong-Kong and Macau are interested in less stringent environmental regulations. Conversely, some countries from OECD members are more interested in high levels of skilled labor and strict environmental regulations.

\subsection{The effect of population through air pollution}

Rapid population growth is the main driving force for air pollution, in particular, in large cities that attract foreign investment and migrant workers. The more population increases, the amount of $\mathrm{CO}_{2}$ emissions also increases. Various types of city activities also result from urban energy consumption, agricultural land, livestock and from population activities. Human growth from year to year increases $\mathrm{CO}_{2}$ emissions. This is generated from the process of respiration carried out at all times.

Increasing the population also tends to change the physical condition of the natural environment to meet the needs of the community both for the economy, education and services. The population growth rate has triggered high urban activities that also have the potential to produce $\mathrm{CO}_{2} . \mathrm{CO}_{2}$ gas is one of the causes of the greenhouse effect and global warming. For iu the concentration of $\mathrm{CO}_{2}$ gas in the atmosphere needs to be controlled.

The industrial capitalism, which he calls the first major transformation of capitalism, causes global ecology to no longer have the carrying capacity for growth, thus giving rise to the concept of green economy which is the pillar of sustainable development.

\section{Methodology}

Data and Model Analysis The data used in this study are annual time series data during the period 2007-2014, and cross section data of developing countries, the analysis of data using panel data (pooled data). 
The models used in this study are:

$$
\text { CO2 }=\alpha+\beta_{1} \text { FDI }+\beta 2 \text { GDP }+\beta 3 \text { Population }+\varepsilon
$$

Where:

$$
\begin{aligned}
& \mathrm{CO} 2=\text { emission } \mathrm{CO}_{2} \text { (air pollution) } \\
& \mathrm{GDP}=\text { Gross Domestic Product } \\
& \mathrm{FDI}=\text { Foreign Direct Investment } \\
& \mathrm{Pop}=\text { Population }
\end{aligned}
$$

To prove whether Haven Pollution Hypothesis occurs in Indonesia can be seen from:

1. If air pollution $\left(\mathrm{CO}_{2}\right)$ in Indonesia is positively related to $\mathrm{FDI}$, then the pollution haven hypothesis is true.

2. If air pollution $\left(\mathrm{CO}_{2}\right)$ in Indonesia is negatively related to FDI, pollution Haven Hypothesis does not occur.

\subsection{Definition of operational variable}

In this research this analysis conducted by analysing the data through some variable that can be defined as below:

\subsubsection{Emission $\mathrm{CO}_{2}$}

$\mathrm{CO}_{2}$ emission is the presence of one or more Physical, Chemical, or Biological substances in the atmosphere in amounts that can endanger the health of humans, animals, and plants, disrupt aesthetics and comfort, or damage property. The unit size used is KT per capita / year.

\subsubsection{Foreign direct invesment (FDI)}

Foreign Investment is foreign investment that is carried out to run a company in a developing country and bear all the risks of such investments directly, and expressed in rupiah per year 


\subsubsection{Gross domestic product (GDP)}

Gross Domestic Product (GDP) can be interpreted as the value of final goods and services produced by various production units in the territory of a country within a year, and expressed in current USD.

\subsection{Population}

Residents are all people domiciled in the geographical area of Indonesia for six months or more and / or those who live less than six months but aim to settle. Variable sizes of millions of people per year.

\section{Results and Analysis}

The result by the data of the research model found the data as attached below:

TABLE 1: Resume results from panel regression data with $\mathrm{CO}_{2}$ as a dependent variable.

\begin{tabular}{lc} 
Independent Variable & Coefficient \\
FDI & $\left.-3.000^{* * *}(-3.40)\right)$ \\
GDI & $8.830^{* * *}(2.40)$ \\
population & $3.851^{* * *}(8.18)$ \\
Constant & $-39.13^{* * *}(-2.29)$ \\
\hline R-squared & 0.9908 \\
Wald Chi2(2) & 46973.08 \\
$\begin{array}{l}\text { Prob>Chi2 } \\
\text { Source: Processed Research Data Value Z-statistics ***, } \\
\text { and }{ }^{* * *} \text { are notations for significant levels at level } 0.10, \\
0.05 \text { and } 0.01\end{array}$
\end{tabular}

From the results it was found that the value of FDI significantly affected the level of $\mathrm{CO}_{2}$ emissions with a negative relationship, this indicates that the greater the value of FDI that occurs in developing countries, will make production technology more efficient and efficient, the application of technology that is more efficient and effective impact on use resources more efficiently and have a positive impact on the environment in the form of reducing emissions. While on the other hand general economic growth enhancers increase the value of $\mathrm{CO}_{2}$ emissions in developing countries, this is in line with EKC, so the data shows that the tendency of economic growth also results in environmental 
damage. This is in line with the findings [15], emphasizing the results, that FDI increases efficiency in the pollution reduction process.

In line with the GDP findings found also population growth contributes pollution towards the same direction, the higher population growth, the greater the contribution to $\mathrm{CO}_{2}$ pollution along with the increasing demand for resources and the increasing variety of economic activities.

This study found that the pollution haven hypothesis was not proven to occur in developing countries and this proved to be significant with the results of FDI values having a negative effect on $\mathrm{CO}_{2}$ emissions. this is supported by the following data:

$\mathrm{CO}_{2}$ emissions from fossil-fuel use and cement production in the top 5 emitting countries and European union
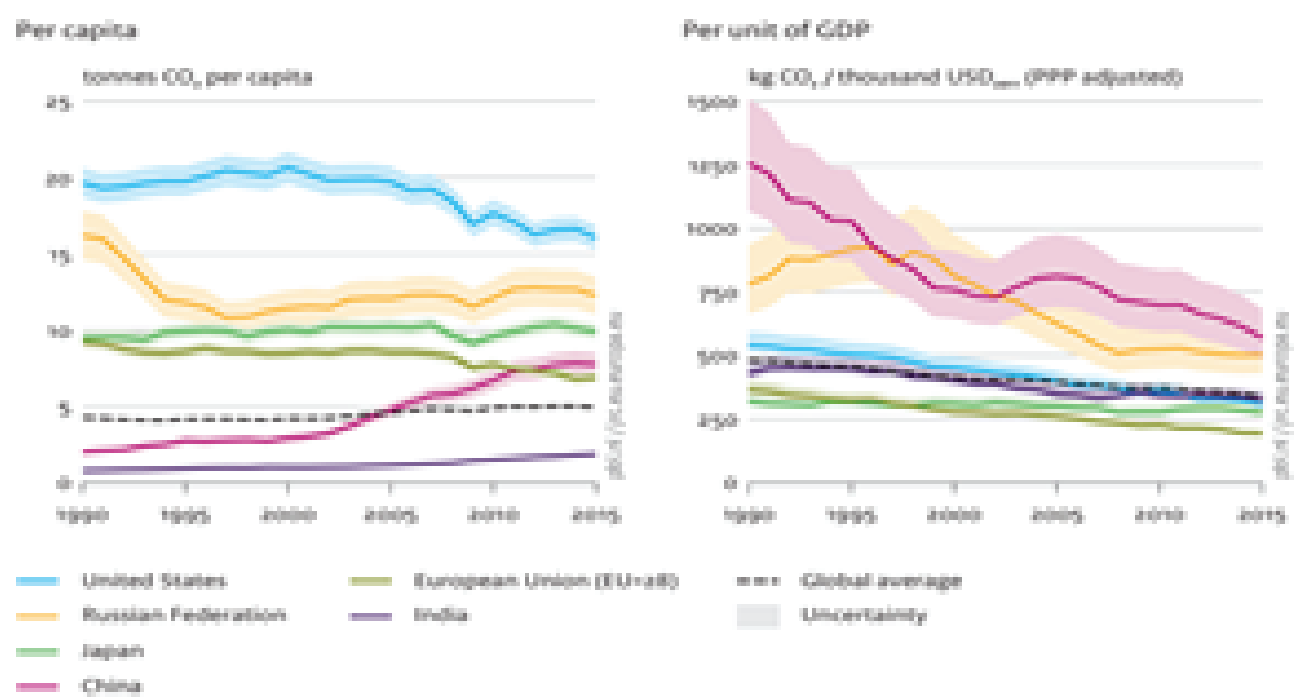

Figure 1: source: edgar v4.3.2 ft2015 (jrc/pbl 2016: notably iea 2014 (suppl. with bp 2016, nbs 2016); unpd 2015 (wpp, rev. 2015).

The value of $\mathrm{CO}_{2}$ emissions that occur is higher not in small countries or developing countries, the $\mathrm{CO}_{2}$ value is greater in the US as per capita, followed by Russia and Japan. Likewise China has a greater emission level with growing economic activity, the value of emissions of these countries is above the world average. Non-Annex I $\mathrm{CO}_{2}$ emissions and drivers(Kaya decomposition)

From the table above it can be seen that per capita emissions increase with increasing GDP and population, this is often with increasing economic activity because the more energy needs that must be met in these economic activities, the above data supports the findings of econometrically processed data, that GDP grows along with the increase in emissions. 


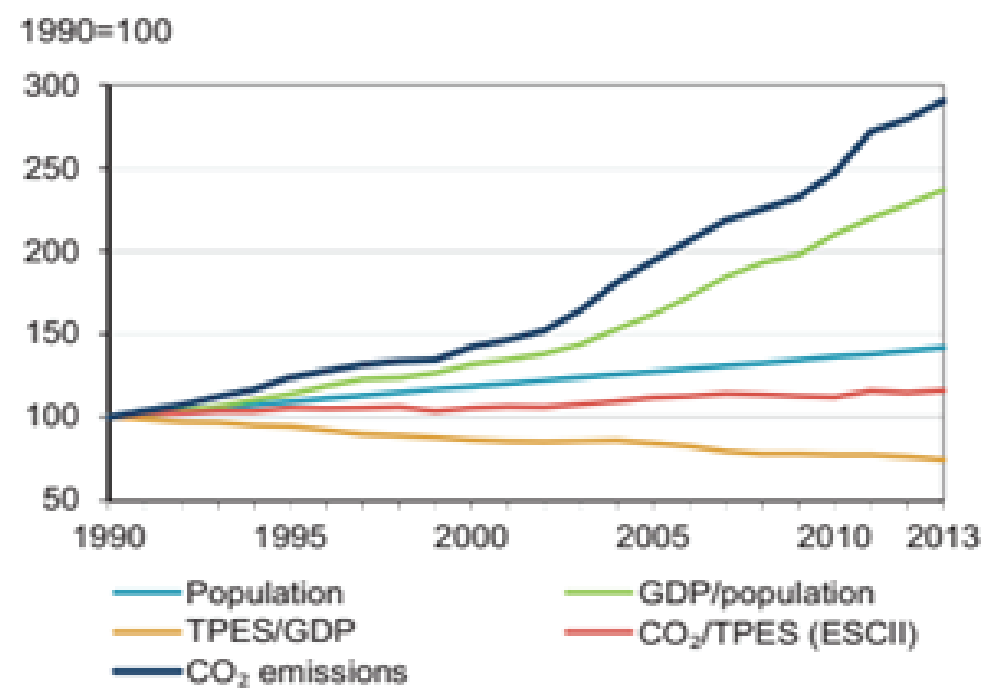

Figure 2: source: edgar v4.3.2 ft2015 (jrc/pbl 2016: notably iea 2014 (suppl. with bp 2016, nbs 2016); unpd 2015 (wpp, rev. 2015).

\section{Conclusion}

In this study found that $\mathrm{CO}_{2}$ emissions in developing countries are influenced by FDI in a negative relationship, this has a good impact on the implementation of economic development. With the increasing amount of FDI occurs, it will improve production technology and production efficiency so that clean technology can be adopted by developing countries which will then lead to a reduction in emission levels.

The GDP and population variables positively influence increasing $\mathrm{CO}_{2}$ emissions, along with the growing economy and increasing population, resulting in increasingly economic activity and greater exploitation of natural resources. This study proves that pollution haven hypothesis does not occur in groups of developing countries. FDI that occurs in developing countries is not because developing countries are a country of pollution or a place of pollution for developed countries, but it is found that FDI has a negative effect which means that the impact of reducing emission levels is by transferring technology and improving production efficiency.

\section{References}

[1] Copeland, B. R. A. Taylor, M.S. (2004). "Trade, Growth And The Environment."Journal Of Economic Literature 42 No.1, P.771

[2] Rukmana, Didi. (2012). Ekonomi Lingkungan Dan Sumber Daya Manusia. Arus Timur.Makassar. 
[3] Grossman, G. M., \& Krueger, A. B. (1991). Environmental impacts of a NorthAmerican Free Trade Agreement. Working Paper 3914. Cambridge MA: National Bureau of Economic Research, NBER.

[4] Arsyad, Lincolin. (2010). Ekonomi Pembangunan Edisi Ke-5. Upp Stim Ykpn. Yogyakarta

[5] Rratnaningsih, m., apriliani, a. T., sudharto,d., \&suparmoko. (2006). Pdrb hijau (produk domestik regional bruto hijau). Yogyakarta: bpfe_yogyakarta.

[6] IEA statistic, 2016, http://www.iea.org/t\&c

[7] HTTP.www.WRI

[8] Brock, W. A., \& Taylor, M. S. (2005). The Green Solow Model. Journal Economic Growth, 15(2010), 127 - 153.

[9] Kirkulak, Berna, Bin Qiu \& Wei Yin. (2011). The Impact of FDI on air quality: evidence from China. Journal of Chinese economic and foreign trade studies. Vol. 4 No.2

[10] Tasri, susanti evi, kaimi, handra, 2016, Application model of green economic growth and economic gap, Int. J. Green Economics, Vol. 10, No. 1, 2016

[11] Munasinghe, M. (2002). The Sustainomic Trans-Disclipnary Meta-Framework For Making Development..More Sustainable:Applications To Energy Issues. International Of Sustainable Development Vol. 4 No. 2: Pp 6-54.

[12] Alguacil, Ma Taresa \& Coadros, Ana \& Orts., Vicente (2002). Foreign Direct Invesment, Exports And Domestic Performance In Mexico: A Causality Analysis. Economic Letters, ElsevierVol. 77 (3), Pages 371-376,November

[13] Eskeland, G. S., \& Harrison, A. E. (1997).Moving to greener pastures? Multinationals and the pollution haven hypothesis (Working Paper 1744). Washington DC: World Bank.

[14] Dean, M.J, Lovely, E. M. and Wang, H. (2008). "Are Foreign Investors Attracted ToWeak Enviromental Regulations? Evaluating The Evidance From China." Journal Of Development Economics Vol. 90 No. 1 Pp 1-13.

[15] Pan, S.B. and Yu, M.Z. (2005), Causality test on the FDI and environment pollution in Jiangsu, Zhejiang and Shanghai, Journal of International Trade, No. 12, pp. 74-9 (Chinese). 